\title{
Association of foetal size and sex with porcine foeto-maternal interface integrin expression
}

\author{
Claire Stenhouse ${ }^{\dagger}$, Charis O Hogg and Cheryl J Ashworth \\ Developmental Biology Division, The Roslin Institute and Royal (Dick) School of Veterinary Studies, University of \\ Edinburgh, Midlothian, UK
}

Correspondence should be addressed to C Stenhouse; Email: clairestenhouse@tamu.edu

${ }^{\dagger}(\mathrm{C}$ Stenhouse is currently at Physiology of Reproduction, Department of Animal Science, Texas A\&M University, College Station, Texas, USA)

\begin{abstract}
Integrins regulate adhesion at the foeto-maternal interface by interacting with secreted phosphoprotein 1 (SPP1) and fibronectin (FN). It is hypothesised that impaired foetal growth of 'runt' piglets is linked to altered integrin signalling at the foeto-maternal interface. Placental and endometrial samples associated with the lightest and closest to mean litter weight (CTMLW) (gestational day (GD18, 30, 45, 60 and 90), of both sex (GD30, 45, 60 and 90) $(n=5-8$ litters/GD), Large White $\times$ Landrace conceptuses or foetuses were obtained. The mRNA expression of the integrin subunits (ITG) ITGA2, ITGAV, ITGB1, ITGB3, ITGB5, ITGB6, ITGB8, SPP1 and $F N$ was quantified by qPCR. Temporal changes in mRNA expression were observed, with different profiles in the two tissues. Endometrial ITGB1 $(P \leq 0.05$, GD45) and SPP1 $(P \leq 0.05$, all GD combined and GD60) expression was decreased in samples supplying the lightest compared to the CTMLW foetuses. Placentas supplying female foetuses had decreased expression of ITGB6 (GD45, $P \leq \mathbf{0 . 0 5})$ and $F N(G D 90, P \leq 0.05)$ compared to those supplying male foetuses. Endometrial samples supplying females had increased ITGB3 $(P \leq 0.05$, GD60) and $F N(P \leq 0.05$, GD30) expression and decreased $S P P 1(P \leq 0.05$, GD60) expression compared to male foetuses. Correlations between mean within-gilt mRNA expression and percentage prenatal survival, number of live foetuses or conceptuses and percentage male foetuses were observed. This study has highlighted novel and dynamic associations between foetal size, sex and integrin subunit mRNA expression at the porcine foeto-maternal interface. Further studies should be performed to improve the understanding of the mechanisms behind these novel findings.

Reproduction (2019) 157 317-328
\end{abstract}

\section{Introduction}

Low birthweight infants have an increased risk of mortality and morbidity and can be classified as small for gestational age (SGA) or intra-uterine growth restricted (IUGR). The pig has a high incidence of naturally occurring low birthweight piglets, with many litters having a growth-restricted or 'runt' piglet that can weigh less than half of the weight of their largest littermates (Widdowson 1971, Ashworth et al. 2001, Wu et al. 2010). Considering the high prevalence of low birth weight piglets, it is essential to improve the understanding of the mechanisms governing foetal growth. It is hypothesised that inadequate conceptus attachment to the endometrium contributes to the large variation in piglet weight and high prevalence of low birthweight piglets.

Integrins (ITGs) are glycoprotein transmembrane receptors which exist as heterodimers composed of noncovalently linked alpha (ITGA) and beta (ITGB) subunits (Giancotti \& Ruoslahti 1999). Integrins play a central role in cell adhesion and have been shown to be critical in the formation of focal adhesions, cell migration, proliferation and the development of the actin cytoskeleton (Irving \& Lala 1995, Schwartz \& Assoian 2001, Gallant et al. 2005, Delon \& Brown 2007). Specific integrin heterodimers can bind to peptides containing an Arg-Gly-Asp (RGD) region, such as secreted phosphoprotein 1 (SPP1, also known as osteopontin (OPN)) and fibronectin (FN). The process of implantation requires significant remodelling of the extracellular matrix at the interface between the conceptus and the mother (Carson et al. 2000, White et al. 2006), which is believed to be partially regulated by integrin signalling. Both SPP1 (Feinberg et al. 1991, Denker 1993, Sutherland et al. 1993, Aplin et al. 1994, Lessey et al. 1994, Ruck et al. 1994, Campbell et al. 1995, Fassler \& Meyer 1995, Schultz \& Armant 1995, Stephens et al. 1995, Yoshimura et al. 1995, Bowen et al. 1996, Shiokawa et al. 1996, 1999, Fazleabas et al. 1997, Schultz et al. 1997, Yelich et al. 1997, Guillomot 1999, Hodivala-Dilke et al. 1999, Johnson et al. 1999, 2001, Kimmins \& MacLaren 1999, Illera et al. 2000, 2003, Bloor et al. 2002, Burghardt et al. 2002, 2009, Kao 
et al. 2002, Qin et al. 2003, Rashev et al. 2005, White et al. 2005, Zheng et al. 2006, Lin et al. 2007, Erikson et al. 2009a, Germeyer et al. 2014, Vélez et al. 2015, 2017, Frank et al. 2017) and FN (Feinberg et al. 1991, Schultz \& Armant 1995, Bowen et al. 1996, Qin et al. 2003, Rashev et al. 2005, Imakawa et al. 2006, Zheng et al. 2006, Vélez et al. 2015, 2017) have been reported to play a role in early gestation in multiple species by regulating integrin signalling. In the pig, trophoblast and uterine luminal epithelial cells have been shown to express ITGAV, ITGA2, ITGA5, ITGB1, ITGB3 and ITGB6 (Bowen et al. 1996, Erikson et al. 2009a, Frank et al. 2017). It has been suggested that ITG $\alpha 5 \beta 1$, ITG $\alpha \vee \beta 3$, ITG $\alpha \vee \beta 6$ and ITG $\alpha \vee \beta 1$ receptors may be able to bind to SPP1, and FN may bind to ITG $\alpha 5 \beta 1$, ITG $\alpha \vee \beta 3$ or ITG $\alpha$ II $\beta 3$ (Humphries et al. 2006). Further, porcine trophoblast cells have been shown to utilise integrin heterodimers containing ITGAV receptors to bind to SPP1 during implantation (Frank et al. 2017).

In addition to a central role in the regulation of implantation and early pregnancy in the pig (Bowen et al. 1996, Rashev et al. 2005, White et al. 2005, Erikson et al. 2009a, Vélez et al. 2015, 2017), integrins and their ligands are expressed at the porcine foetomaternal interface at multiple gestational days (GD) (Garlow et al. 2002, White et al. 2005, Hernández et al. 2013, Vélez et al. 2015, 2017, Frank et al. 2017, Steinhauser et al. 2017). Considering the non-invasive nature of the porcine placenta (Montiel et al. 2013), and the substantial remodelling that must occur to ensure adequate nutrient transfer to the foetus (Vallet \& Freking 2007), it is unsurprising that adhesive processes must be present throughout gestation to maintain a successful pregnancy.

It is hypothesised that the mRNA expression of integrin subunits, $F N$ and $S P P 1$, will be decreased in placental and endometrial samples associated with the lightest conceptuses or foetuses compared to their normal-sized littermates throughout gestation. To test this hypothesis, samples were compared within litter at five GDs of interest.

It has previously been demonstrated that significant variation in foetal size can be observed at GD30 (Pettigrew et al. 1986, Wise et al. 1997, Finch et al. 2002, Foxcroft \& Town 2004, Foxcroft et al. 2006), which is thought to be reflective of the postnatal withinlitter variation in the piglet size observed. Therefore, placental and endometrial samples from early gestation were utilised as part of this study. During pregnancy, temporal changes in the rate of foetal and placental growth can be observed (Marrable 1971). After the initially fast period of placental growth, the growth rate of the porcine placenta plateaus in mid-gestation, whereby instead of continuing to increase in weight, the structure of the placenta undergoes extensive remodelling to increase the surface area available for nutrient exchange with the developing foetus (Vallet
\& Freking 2007). Whilst the placental growth rate is decreased, the foetus is undergoing rapid growth, placing large demands upon the placenta. This study has utilised placental and endometrial samples from GD18, 30, 45, 60 and 90, which were selected to allow investigation of these tissues throughout gestation due to the dynamic relationship between foetal and placental growth at the foeto-maternal interface.

Recent literature has suggested that sexual dimorphism in placental development exists in humans (Rosenfeld 2015, Kalisch-Smith et al. 2017), which may translate to the observed sexual dimorphism in phenotype in response to adverse conditions during pregnancy. In the pig, it has been suggested that males are at a disadvantage compared to their female littermates postnatally (Baxter et al. 2012). Further, recent investigations in our laboratory have reported sexual dimorphism in both placental and endometrial vascularity in the pig (Stenhouse 2018, Stenhouse et al. 2018a). Considering this, it is hypothesised that decreased expression of the integrin receptors and their ligands will be observed in placental and endometrial samples supplying male foetuses compared to their female littermates.

The number of live born piglets per year is an economically important factor for the pig industry (Koketsu et al. 2017). Further, the sex ratio of the litter is known to influence reproductive success (Lamberson et al. 1988, Drickamer et al. 1997, 1999, Huhn et al. 2002, Górecki 2003). Considering this, and the proposed role of integrin signalling at the foeto-maternal interface, the relationship between integrin mRNA expression and percentage prenatal survival, number of live foetuses and the percentage of male foetuses in the litter was investigated.

\section{Materials and methods}

All procedures were performed with approval from The Roslin Institute (University of Edinburgh) Animal Welfare and Ethical Review Board and in accordance with the U.K. Animals (Scientific Procedures) Act, 1986.

\section{Experimental animals and sample collection}

Large White $\times$ Landrace gilts (age 11-14 months; $n=31$ ) were observed daily for signs of oestrus and were housed in groups of 6-8 animals per pen. Oestrous cyclicity and ovarian function were controlled in accordance with routine normal practice at The Roslin Institute Large Animal Unit. In a subset of gilts (distribution between the GD investigated indicated in Supplementary Table 1, see section on supplementary data given at the end of this article) oestrus was synchronised by daily feeding of $20 \mathrm{mg}$ Altrenogest (Regumate, Hoechst Roussel Vet Ltd.) for 18 days followed by injection of pregnant mare serum gonadotrophin (PMSG; Intervet UK Ltd) and human chorionic gonadotrophin (hCG; Intervet UK Ltd) (Stenhouse et al. 2018a). All gilts were inseminated twice daily for the 
duration of oestrus with semen from one of four Large White boars. The boars used were equally distributed throughout the GD to minimise any effect of sire. The first day of insemination was assigned as GD0 and samples were obtained at GD18, 30, 45, 60 and 90. Gilts were killed at the GD of interest with sodium pentobarbitone $20 \% \mathrm{w} / \mathrm{v}$ (Henry Schein Animal Health) at a dose of $0.4 \mathrm{~mL} / \mathrm{kg}$ by intravenous injection via a cannula inserted in the ear vein. Following confirmation of death, mid-ventral incision revealed the reproductive tract. The tract was lifted from the body cavity and placed in a dissecting tray. Both uterine horns were dissected, from the ovary towards the cervix. The uterine lumen was occluded between each foeto-placental unit by tying with string to ensure that the tissue associated with particular conceptuses or foetuses could be identified later.

At GD18, the uterine tract was rinsed with saline and a string was used to tie the end of the right and left uterine horns at the bifurcation. The uterine horns were cut between the two pieces of string and each uterine horn was placed in a floatation device. The device contained a solution to preserve the integrity of the RNA (700g ammonium sulphate (SLS) was dissolved in $935 \mathrm{~mL}$ of RNase-free water with heat and stirring). Once dissolved, $25 \mathrm{~mL}$ of $1 \mathrm{M}$ sodium citrate (Fisher Scientific) and $40 \mathrm{~mL}$ of $0.5 \mathrm{M}$ EDTA were added. The solution was adjusted to $\mathrm{pH} 5.2$ using concentrated sulphuric acid and stored at room temperature until required. Using dissection scissors, the uterine horn was opened along the mesometrial side, and the conceptuses floated in the solution. Individual conceptuses were removed from the floatation device with forceps and weighed in a cryovial (Starlab). The uterine lumen was occluded between each conceptus to ensure that endometrial samples associated with particular conceptuses could be identified. The lightest and CTMLW conceptus was identified based on weight and snap-frozen in liquid nitrogen and stored at $-80{ }^{\circ} \mathrm{C}$ for RNA extraction.

On the remaining GD investigated, foetuses were identified as 'live' or 'dead' based on their morphology at the time of dissection and were weighed. At GD45, 60 and 90, foetal sex was determined morphologically. DNA was isolated from the GD30 foetuses using the DNeasy Blood and Tissue DNA extraction kit (Qiagen), and PCR was performed for the sexdetermining region $\mathrm{Y}$ (Sry) - a region of the $\mathrm{Y}$ chromosome - as previously described (Stenhouse et al. 2018b) to determine the sex of the foetuses. The lightest and CTMLW foetuses (GD30), of both sex (GD45, 60 and 90), were identified based on foetal weight. From the anti-mesometrial side, placental and endometrial samples were taken from each foeto-placental unit of interest, snap-frozen in liquid nitrogen and stored at $-80{ }^{\circ} \mathrm{C}$ for RNA extraction.

\section{Analysis of $\mathrm{mRNA}$ expression by $q P C R$}

\section{Total RNA extraction and CDNA synthesis}

RNA was extracted from 20 to $50 \mu$ g of snap-frozen placental and endometrial samples as previously described (Stenhouse et al. 2018a). The RNA was quantified, and the quality was assessed spectrophotometrically using a Nanodrop ND-1000
(Labtech International Ltd.) and electrophoretically using a Tapestation 2200 (Agilent Technologies). The mean A260/ A280 and RNA Integrity Number Equivalent (RINe) for samples within each GD are detailed in Supplementary Table 2. Extracted RNA was stored at $-80{ }^{\circ} \mathrm{C}$ until required. If the RINe value obtained remained lower than the ranges detailed in Supplementary Table 2, the sample was excluded from the analyses.

cDNA was prepared from $0.3 \mu \mathrm{g}$ of RNA with SuperScript III reverse transcriptase (Life Technologies) following the manufacturer's instructions. Each reaction contained $250 \mathrm{ng}$ random primers (Promega) and 40 units RNaseln (Promega). Negative controls without reverse transcriptase were included to check for genomic contamination. Reverse transcription was performed in duplicate for each sample and pooled, and the cDNA was stored at $-20^{\circ} \mathrm{C}$ until required.

\section{Relative expression of candidate genes}

Quantitative PCR was performed on a Stratagene MX3000 instrument using Platinum SYBR Green SuperMixUTG (Life Technologies) using cDNA from placental (GD30, 45,60 and 90; $n=6,6,6$ and 8 litters respectively) and endometrial (GD18, 30, 45, 60 and 90; $n=5,5,6,6$ and 6 litters respectively) samples. The samples were associated with the lightest and CTMLW conceptuses or foetuses at GD18 and 30, and the lightest and CTMLW foetuses of both sex at GD45, 60 and 90. The final concentrations of magnesium, ROX reference dye and each primer were $3 \mathrm{mM}$, $50 \mathrm{nM}$ and $400 \mathrm{nM}$ respectively in a $25 \mu \mathrm{L}$ reaction volume. All qPCRs were carried out at an annealing temperature of $60{ }^{\circ} \mathrm{C}$ and dissociation curves consisting of single peaks were generated. The mRNA expression of ITGA2, ITCAV, ITGB1, ITGB3, ITGB5, ITGB6, ITGB8, SPP1 and FN was quantified in both tissues (King et al. 2011, Hernández et al. 2013, Frank et al. 2017). Appropriate reference genes were identified by analysis of 11 candidate reference genes (Erkens et al. 2006, Nygard et al. 2007) using geNORM V3.5 (Ghent University Hospital, Centre for Medical Genetics). The reference genes TBP1 (TATA box-binding protein) and HPRT1 (hypoxanthine phosphoribosyltransferase 1) were utilised to normalise placental mRNA expression, and endometrial mRNA expression was normalised using the reference genes TBP1, YWHAZ (Tyrosine 3-monooxygenase/tryptophan 5 -monooxygenase activation protein and zeta polypeptide) and TOP2B (Topoisomerase II beta). The primer sequences for all genes are detailed in Supplementary Table 3.

Serial dilutions of pooled cDNA ranging from 1:5 to 1:640 in nuclease-free water were used as standards. Sample cDNA was diluted $1: 25$ and $5 \mu \mathrm{L}$ of diluted sample, standard or control were added per well. Each plate contained duplicate wells of a no template control, standards, sample cDNA and reverse transcriptase blanks. Data were analysed using qbase+ software V3.0 (Biogazelle). A target- and run-specific strategy was employed and the results, normalised to the two reference genes, were scaled to the minimum sample. The mean slope, intercept, PCR efficiency and $R^{2}$ values are detailed in Supplementary Table 4. 


\section{Statistical analysis}

All statistical analyses were performed using Minitab 17 or GenStat 13.1 (VSN International Ltd.). The normalised mean value for each placental and endometrial sample was taken and the normality of the distribution of the data was assessed by an Anderson-Darling test. If a $P$ value of $\leq 0.05$ was obtained, then the data were not considered to have a normal distribution. Outliers were tested for using a Grubbs outlier test and were excluded systematically, with normality within each group being reassessed following each exclusion. $\log _{10}$ transformations were carried out where appropriate to improve the normality of the distribution of the data. The effect of foetal size was assessed by comparing values for the true lightest and true CTMLW at GD18, 30, 45, 60 and 90. Effects of foetal sex were assessed by comparing values from placental and endometrial samples supplying foetuses of both sex at GD30, 45, 60 and 90. Where data had a normal distribution, ANOVA for GD, foetal size or sex was performed, with a block for gilt to account for the common maternal environment. A post hoc Tukey test was performed where appropriate. Where data did not have a normal distribution, Kruskal-Wallis and Mann Whitney tests were performed. Within gilt, the mean expression for each gene of interest was calculated within tissue. Pearson's correlations were performed within GD to determine the association between the mean gene expression within gilt and the percentage of males in the litter (sex ratio), percentage prenatal survival (calculated by dividing the number of live foetuses by the number of corpora lutea, multiplied by 100) and the number of live foetuses. In all experiments, results were considered significant when $P \leq 0.05$, tending towards significant when $P$ was $>0.05$ and $<0.1$ and not significant when $P \geq 0.1$.

\section{Results}

\section{Temporal changes in integrin mRNA expression}

No significant day effect was observed in the placental expression of ITGB5 or SPP1 (Fig. 1E and I). An overall day effect was observed in the placental expression of ITGA2 ( $P \leq 0.05$; Fig. 1A), with GD30 placentas having decreased expression compared to the other GD investigated. Placental ITGAV expression was influenced by GD $(P \leq 0.05$; Fig. 1B), with decreased expression observed at GD60 compared to GD30 and GD45. An overall GD effect was observed in the placental expression of ITGB1 ( $P \leq 0.001$; Fig. 1C), with increased expression observed at GD45 and GD90 compared to GD30 and GD60. Placental ITGB3 expression was decreased at GD60 and GD90 compared to GD45 $(P \leq 0.05$; Fig. 1D). Temporal changes in the placental expression of ITGB6 were observed ( $P \leq 0.01$; Fig. $1 \mathrm{~F})$, with low placental expression at GD30, which significantly increased at GD45. Placental ITCB6 expression then significantly increased to its peak expression level at GD90. Placental ITGB8 expression increased with advancing gestation ( $P \leq 0.01$; Fig. $1 \mathrm{G})$, with a significant increase observed between GD30 and GD45. Placental $F N$ expression varied throughout gestation $(P \leq 0.01$; Fig. $1 \mathrm{H})$.

An overall GD effect was observed in ITGA2 endometrial expression $(P \leq 0.05$; Fig. 2A). The endometrial expression of ITCAV ( $P \leq 0.001$; Fig. 2B) and ITGB3 $(P \leq 0.01$; Fig. 2D) were decreased at GD30 compared to the other GD investigated. During
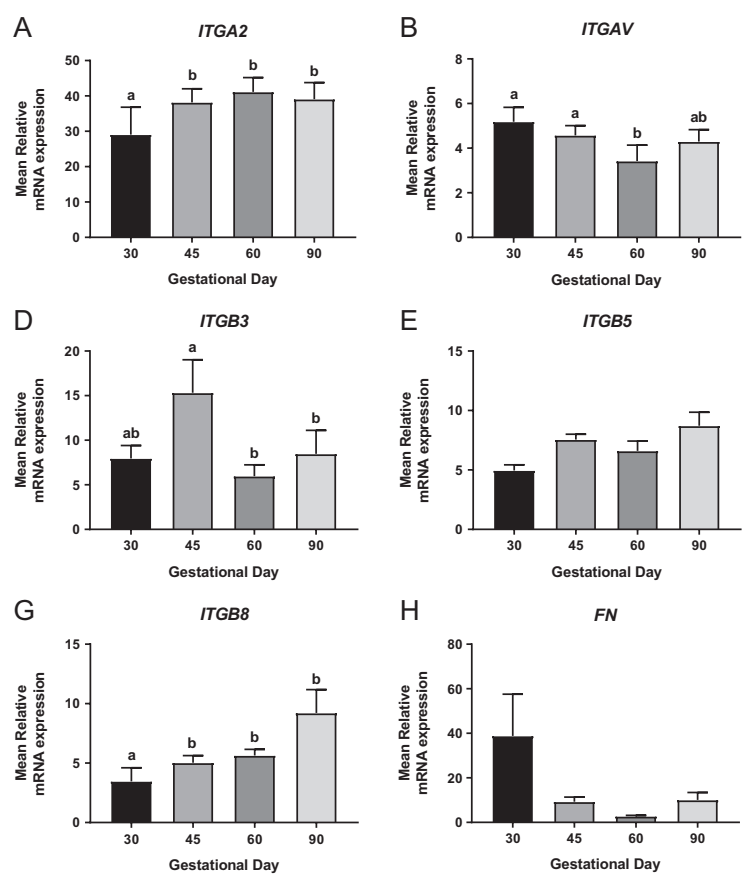

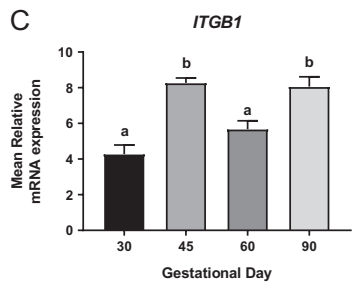

F
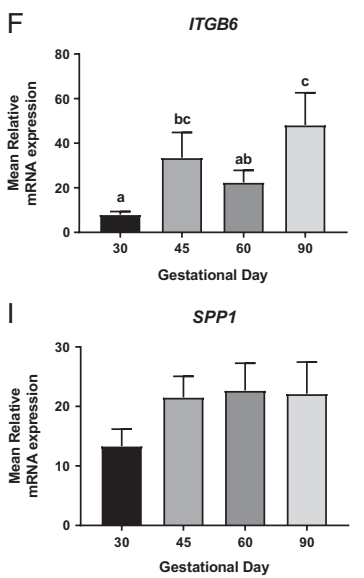

Figure 1 Integrin mRNA expression in placental tissues on days 30, 45, 60 and 90 of pregnancy. mRNA expression of ITGA2 (A), ITGAV (B), ITGB1 (C), ITGB3 (D), ITCB5 (E), ITGB6 (F), ITGB8 (G), FN (H) and SPP1 (I) in placental samples at GD30, 45, 60 and 90. Error bars represent S.E.M. $n=9-23$ foetuses/GD. 

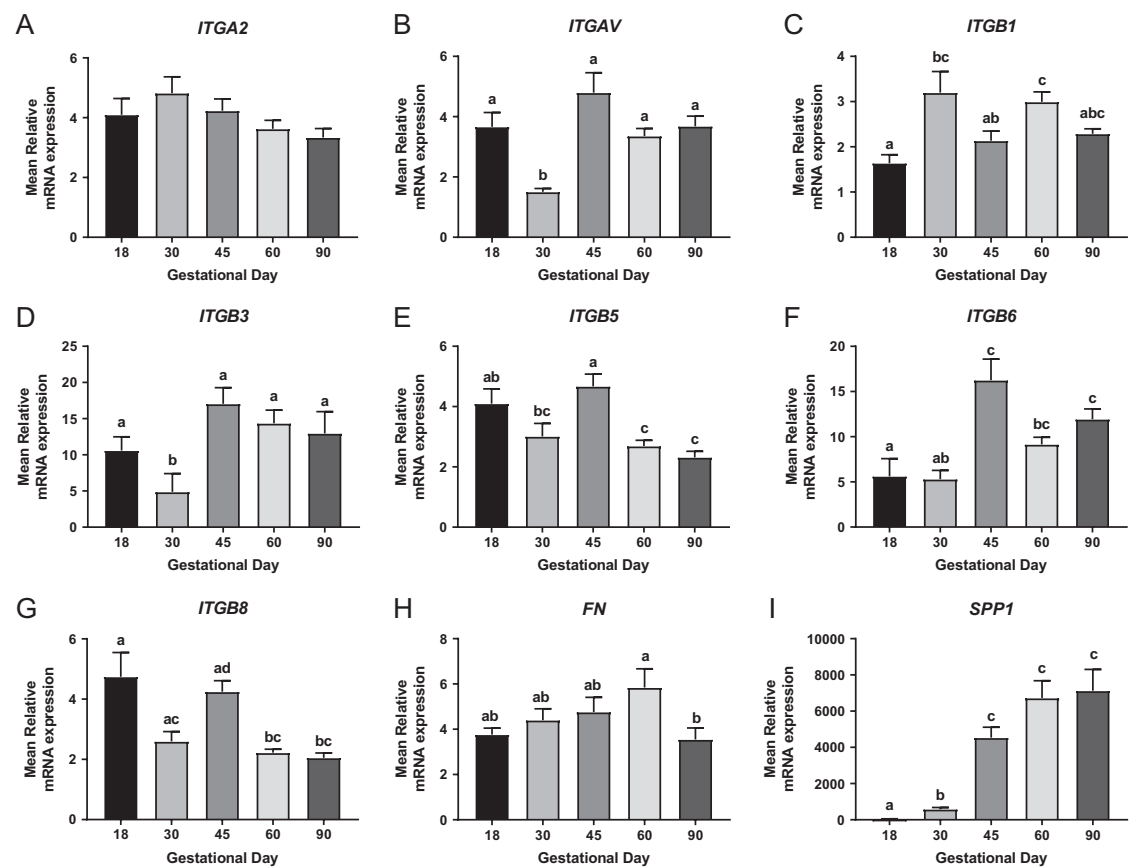

Figure 2 Integrin mRNA expression in endometrial tissues on days 18, 30, 45, 60 and 90 of pregnancy. mRNA expression of ITGA2 (A), ITGAV (B), ITGB1 (C), ITGB3 (D), ITGB5 (E), ITGB6 (F), ITGB8 (G), FN (H) and SPP1 (I) in endometrial samples at GD18, 30, 45, 60 and 90. Error bars represent S.E.M. $n=9-30$ foetuses/GD.

gestation, ITGB $1(P \leq 0.01$; Fig. $2 C)$ and ITGB $8(P \leq 0.001$; Fig. 2G) endometrial expression fluctuated. Endometrial ITGB5 expression also fluctuated throughout gestation $(P \leq 0.001$; Fig. 2E), with decreased expression observed at GD30, GD60 and GD90 compared to GD18 and GD45. ITGB6 endometrial expression was increased in mid and late gestation compared to early gestation, with a notable increase in expression observed between GD30 and GD45 ( $P \leq 0.001 ;$ Fig. 2F). Endometrial
SPP1 expression increased with advancing gestation $(P \leq 0.001$; Fig. 2l).

\section{Associations between foetal size and integrin mRNA expression}

No statistically significant associations between foetal size and placental expression of ITGAV (Fig. 3B), ITGB1 (Fig. 3C), ITGB3 (Fig. 3D), ITGB5 (Fig. 3E),
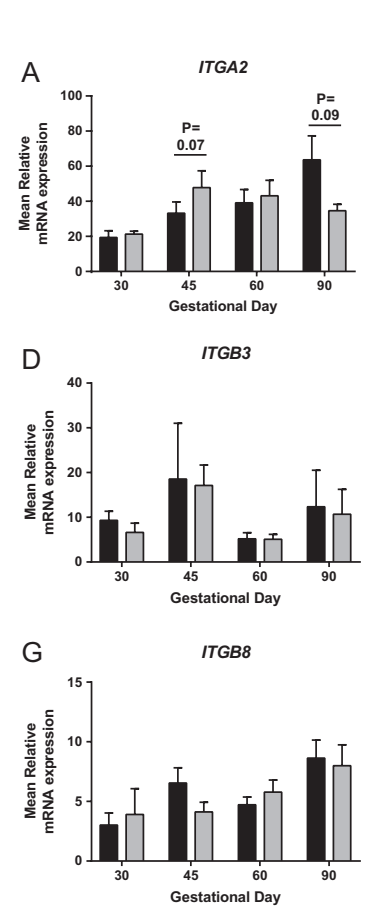
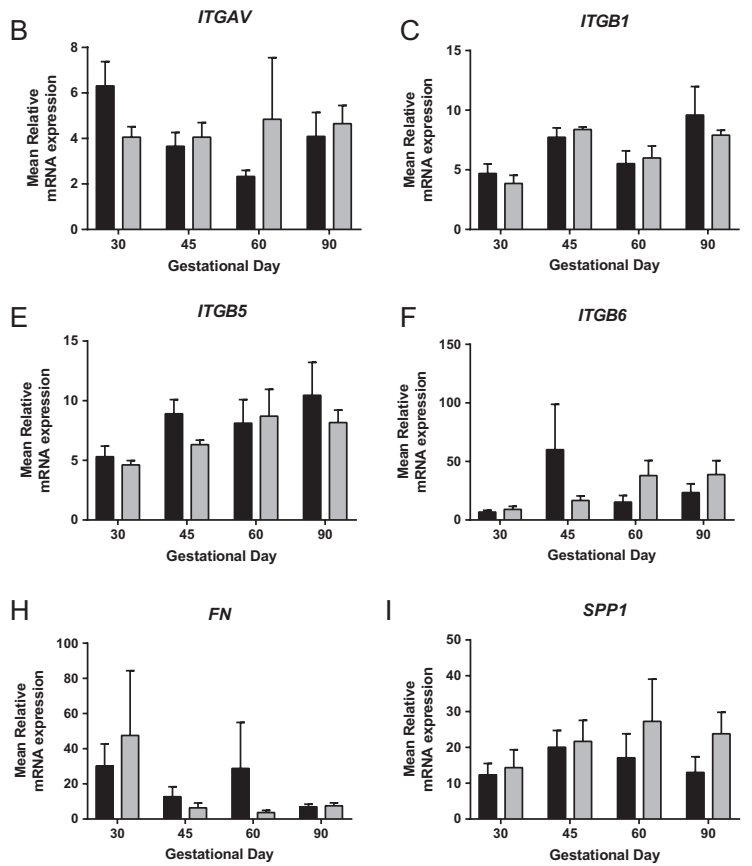

Figure 3 Integrin mRNA expression in placental tissues associated with the lightest and CTMLW conceptuses and foetuses on days 30, 45, 60 and 90 of pregnancy. mRNA expression of ITGA2 (A), ITGAV (B), ITGB1 (C), ITGB3 (D), ITGB5 (E), ITGB6 (F), ITGB8 (G), $F N(\mathrm{H})$ and SPP1 (I) in placental samples associated with the lightest and CTMLW foetuses at GD30, 45, 60 and 90. Error bars represent S.E.M. $n=4-7$ foetuses/GD. 
ITGB6 (Fig. 3F), ITGB8 (Fig. 3G), FN (Fig. 3H) or SPP1 (Fig. 3I) were observed. At GD45 ( $P=0.07$; Fig. 3A), placental samples supplying the lightest foetuses tended to have increased ITGA2 expression compared to those supplying the CTMLW foetuses. The direction of this difference switched at GD90 ( $P=0.09$; Fig. 3A), with placental samples supplying the lightest foetuses having decreased ITGA2 expression compared to those supplying the CTMLW foetuses.

No statistically significant associations between conceptus or foetal size and endometrial expression of ITCA2 (Fig. 4A), ITGAV (Fig. 4B), ITCB3 (Fig. 4D), ITGB5 (Fig. 4E), ITGB6 (Fig. 4F) or FN (Fig. 4H) were observed. Endometrial ITGB1 expression was decreased in samples supplying the lightest foetuses compared to those supplying the CTMLW foetuses at GD45 ( $P \leq 0.05$; Fig. 4C). At GD30, a trend towards endometrial samples supplying the lightest foetuses having increased ITGB5 expression compared to samples supplying the CTMLW foetuses was observed $(P=0.07$; Fig. 4E). Further, endometrial samples associated with the lightest conceptuses tended $(P=0.09$; Fig. 4G) to have increased ITGB8 expression compared to the CTMLW conceptuses at GD18. An overall size effect in SPP1 expression was observed $(P \leq 0.05$; Fig. 4l), with a statistically significant decrease in expression observed in endometrial samples supplying the lightest foetuses compared to the CTMLW foetuses at GD60 $(P \leq 0.05)$.

\section{Associations between foetal sex and integrin mRNA expression}

No statistically significant associations between foetal sex and placental expression of ITGA2 (Fig. 5A), ITGAV (Fig. 5B), ITGB1 (Fig. 5C), ITGB3 (Fig. 5D), ITGB5 (Fig. 5E), ITGB8 (Fig. 5G) or SPP1 (Fig. 5I) were observed. Significant associations between foetal sex and ITGB6 (GD45 $P \leq 0.05$; Fig. 5F) and $F N($ GD90 $P \leq 0.05$; Fig. 5H) expression were observed, with placentas associated with female foetuses having decreased expression compared to those associated with male foetuses.

No statistically significant associations between foetal sex and endometrial expression of ITGA2 (Fig. 6A), ITGAV (Fig. 6B), ITGB1 (Fig. 6C), ITGB5 (Fig. 6E), ITGB6 (Fig. 6F) or ITGB8 (Fig. 6G) were observed. Endometrial samples supplying females at GD60 had increased ITGB3 expression compared to those supplying male foetuses $(P \leq 0.05$; Fig. 6D). At GD30, FN expression was increased in endometrial samples supplying females compared to those supplying male foetuses $(P \leq 0.05$; Fig. $6 \mathrm{H})$. SPP1 endometrial expression was decreased in samples supplying female foetuses compared to their male littermates at GD60 ( $P \leq 0.05$; Fig. 6I).

\section{Associations between mean gilt placental and endometrial integrin expression and litter characteristics}

At GD30, an inverse correlation between mean placental ITCB1 expression and percentage of males in the litter
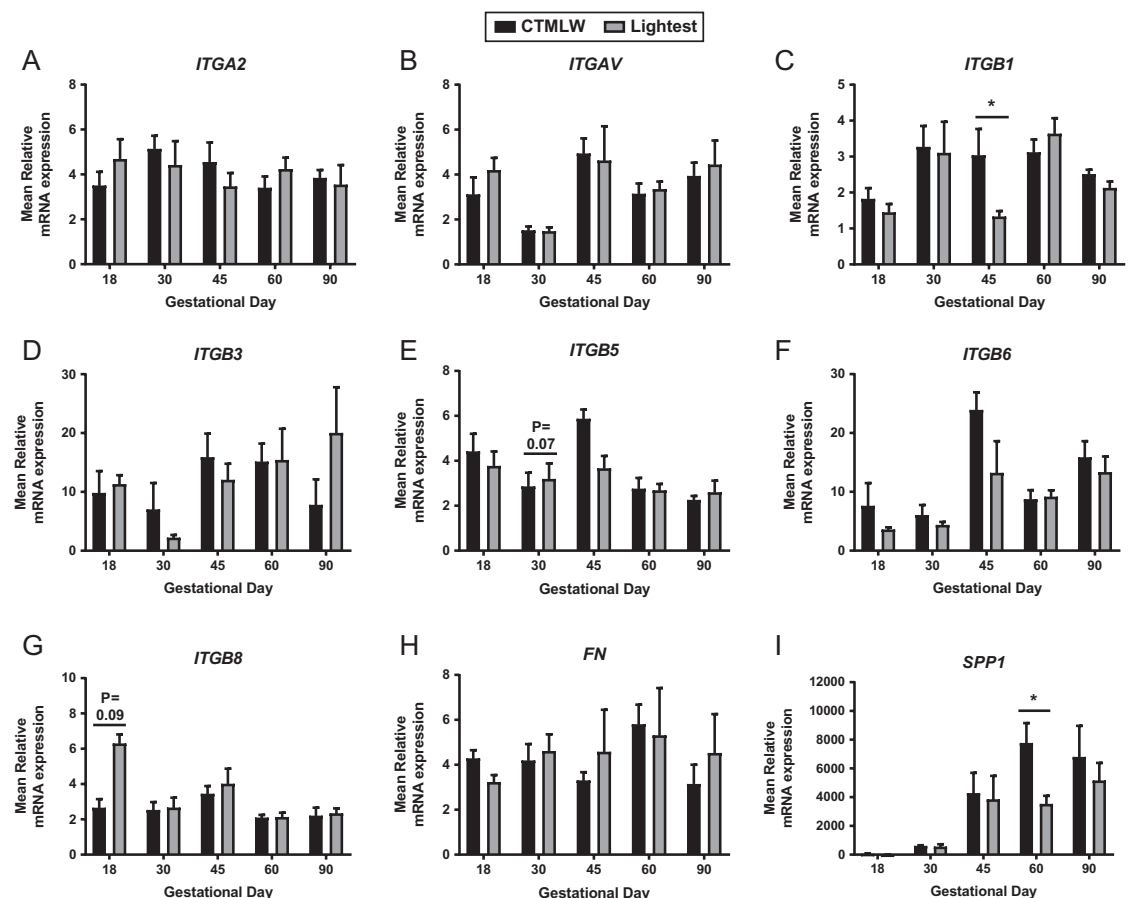

Figure 4 Integrin mRNA expression in endometrial tissues associated with the lightest and CTMLW conceptuses and foetuses on days $18,30,45,60$ and 90 of pregnancy. mRNA expression of ITGA2 (A), ITGAV (B), ITGB1 (C), ITGB3 (D), ITGB5 (E), ITGB6 (F), ITGB8 (G), FN (H) and SPP1 (I) in endometrial samples associated with the lightest and CTMLW conceptuses and foetuses at GD18, 30, 45, 60 and 90. Error bars represent S.E.M. ${ }^{*} P \leq 0.05 . n=3-8$ foetuses/GD. 

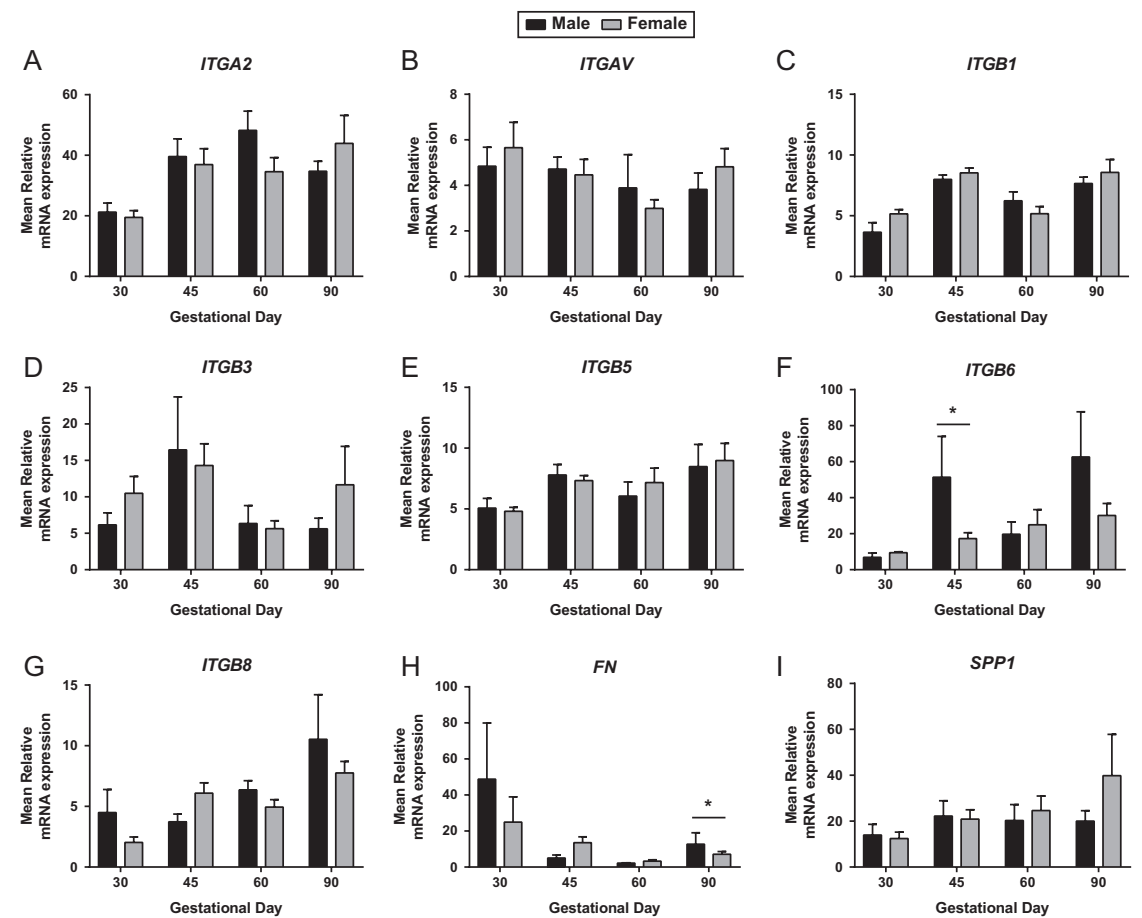

Figure 5 Integrin mRNA expression in placental tissues associated with male and female foetuses on days 30, 45, 60 and 90 of pregnancy. mRNA expression of ITGA2 (A), ITGAV (B), ITGB1 (C), ITGB3 (D), ITGB5 (E), ITGB6 (F), ITGB8 $(\mathrm{G}), F N(\mathrm{H})$ and SPP1 $(\mathrm{I})$ in placental samples associated with male and female foetuses at GD30, 45, 60 and 90. Error bars represent S.E.M. ${ }^{*} P \leq 0.05 . n=4-12$ foetuses/GD.

was observed $(P \leq 0.01$; Table 1). Placental ITGAV (GD60 and GD90 $P \leq 0.05)$, ITGB5 (GD90 $P \leq 0.001)$, ITGB6 (GD90 $P \leq 0.01)$, ITGB8 (GD90 $P \leq 0.01)$ and $F N$ $($ GD90 $P \leq 0.001)$ expression were positively correlated with the number of live foetuses (Table 1).

A positive correlation between both mean endometrial ITGB6 (GD45 $P \leq 0.05$ ) and $F N \quad$ (GD90 $P \leq 0.05$ ) expression and the percentage of males was observed (Table 1). Both endometrial SPP1 (GD18 $P \leq 0.05)$ and ITGAV (GD45 $P \leq 0.01)$ expression were positively correlated with percentage prenatal survival (Table 1). Endometrial ITGB5 (GD18 $P \leq 0.01$ ) and ITGB8 (GD30 $P \leq 0.05)$ were inversely correlated with the number of live conceptuses or foetuses (Table 1).

\section{Discussion}

Integrin signalling has been heavily implicated in the establishment and maintenance of pregnancy by regulating adhesion at the foeto-maternal interface.
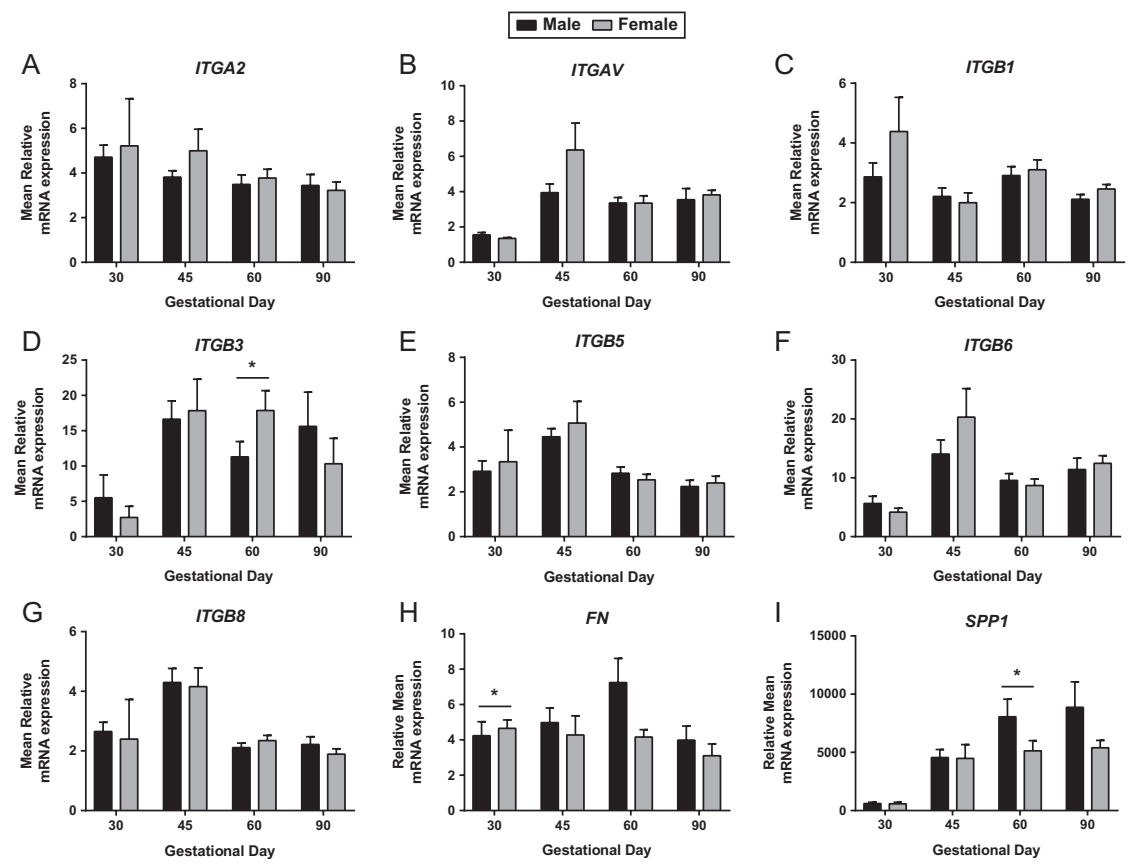

Figure 6 Integrin mRNA expression in endometrial tissues associated with male and female foetuses on days 30, 45, 60 and 90 of pregnancy. mRNA expression of ITGA2 (A), ITGAV (B), ITGB1 (C), ITGB3 (D), ITGB5 (E), ITGB6 (F), ITGB8 $(\mathrm{G}), F N(\mathrm{H})$ and SPP1 $(\mathrm{I})$ in endometrial samples associated with male and female foetuses at GD30, 45, 60 and 90. Error bars represent S.E.M. ${ }^{*} P \leq 0.05 . n=3-16$ foetuses/GD. 
Table 1 Significant correlations between integrin mRNA expression and litter characteristics.

\begin{tabular}{|c|c|c|c|c|c|c|c|}
\hline Gestational day & Tissue & Gene & Variable & RSq (\%) & $P$ value & Number XY pairs & Positive/Negative \\
\hline 30 & Placenta & ITGB1 & Percentage male foetuses & 85.9 & $\leq 0.01$ & 6 & Negative \\
\hline 60 & Placenta & ITGAV & Number of live foetuses & 64.6 & $\leq 0.05$ & 6 & Positive \\
\hline 90 & Placenta & ITGAV & Number of live foetuses & 70.3 & $\leq 0.05$ & 7 & Positive \\
\hline 90 & Placenta & ITGB5 & Number of live foetuses & 90.0 & $\leq 0.001$ & 7 & Positive \\
\hline 90 & Placenta & ITGB6 & Number of live foetuses & 74.0 & $\leq 0.01$ & 7 & Positive \\
\hline 90 & Placenta & ITGB8 & Number of live foetuses & 76.2 & $\leq 0.01$ & 7 & Positive \\
\hline 90 & Placenta & $F N$ & Number of live foetuses & 89.3 & $\leq 0.001$ & 7 & Positive \\
\hline 18 & Endometrium & SPP1 & Percentage prenatal survival & 79.7 & $\leq 0.05$ & 5 & Positive \\
\hline 18 & Endometrium & ITGB5 & Number of live conceptuses & 94.7 & $\leq 0.01$ & 5 & Negative \\
\hline 30 & Endometrium & ITGB8 & Number of live foetuses & 91.1 & $\leq 0.05$ & 4 & Negative \\
\hline 45 & Endometrium & ITGB6 & Percentage male foetuses & 77.9 & $\leq 0.05$ & 6 & Positive \\
\hline 45 & Endometrium & ITGAV & Percentage prenatal survival & 84.3 & $\leq 0.01$ & 6 & Positive \\
\hline 90 & Endometrium & $F N$ & Percentage male foetuses & 73.1 & $\leq 0.05$ & 6 & Positive \\
\hline
\end{tabular}

This study demonstrated an association between mRNA expression of integrins and their ligands, and foetal size at the porcine foeto-maternal interface. There were also novel relationships between foetal sex and both endometrial and placental mRNA expression. Intriguingly, differences in gene expression observed in placental and endometrial tissue appear to occur independently of one another.

This study identified novel associations between foetal size and the endometrial expression of ITGB1 and SPP1. In humans, it has been shown that extravillous trophoblast cells in term placentas which supplied IUGR infants had decreased expression of ITG $\alpha 2 \beta 1$, ITG $\alpha 3 \beta 1$ and ITG $\alpha 5 \beta 1$ integrin receptors compared to those which supplied normally grown infants (Zygmunt et al. 1997). In the current study, endometrial samples supplying the lightest foetuses had decreased ITCB1 expression at GD45 compared to those supplying their normal-sized littermates, reinforcing the suggestion ITGB1 and its ligands may have a role in the regulation of foetal growth in the pig. Further, the ITG $\alpha 5 \beta 1$ receptor has been suggested to bind both FN and SPP1 at the foeto-maternal interface in the pig (Frank et al. 2017). Whilst no decrease in the expression of SPP1 or FN were observed in the endometrial samples supplying the lightest foetuses compared to their normal-sized littermates at GD45, decreased endometrial SPP1 expression was observed at GD60.

Emerging evidence in humans suggests that sexual dimorphism in placental development is responsible for sexual differences to disease susceptibility postnatally (Rosenfeld 2015, Kalisch-Smith et al. 2017). It has been proposed that male new-born piglets have a survival disadvantage compared to their female littermates (Baxter et al. 2012). However, whether this difference arises prenatally due to sexual dimorphism in placental development has not been determined in the pig. Currently, the suggestion of sexual dimorphism in placental or endometrial integrin expression in any species has not been explored. However, in a recent RNA sequencing experiment using human placentas from 10.5 to 13.5 weeks, it was identified that placentas supplying female foetuses had increased ITCB8 expression compared to those supplying males (Gonzalez et al. 2018).

Endometrial FN and ITCB3 expression were increased in samples associated with female foetuses compared with their male littermates at GD30 and 60 respectively. The differential expression of $F N$ in the endometrium but not the placenta at this early stage of gestation may indicate the presence of differential signalling between the conceptus and the endometrium in early gestation, although the mechanisms behind this require further investigation.

An inverse relationship between the percentage of males in the litter and placental ITGB1 (GD30) expression and positive correlations between both endometrial ITGB6 (GD45) and FN (GD90) expression and the percentage of males in the litter were observed. Intriguingly, whilst these results do not mirror the sex differences observed within tissue within GD, placental ITGB6 and FN were demonstrated to be associated with foetal sex at GD45 and GD90 respectively. Interestingly, endometrial ITGB5 and ITGB8 expression were inversely correlated with the number of live conceptuses or foetuses in early gestation, whereas in late gestation placental ITGAV, ITGB5, ITGB6, ITGB8 and FN expression were positively correlated with the number of live foetuses. The width of the folded bilayer at the foetomaternal interface is known to increase significantly from GD65 to GD105 to increase the available surface area for exchange, allowing adequate nutrient transfer to meet the demands of the exponentially growing foetus (Vallet \& Freking 2007). Further, there is some evidence to suggest that as litter size increases, uterine capacity becomes a limiting factor (Ford et al. 2002, Vallet et al. 2014), resulting in smaller placentas. It is proposed that increased remodelling of the interface must occur to attempt to improve placental efficiency and maintain adequate nutrient transfer to the developing foetus. The observed increase in gene expression in late gestation would suggest increased cell adhesion during this 
period of remodelling. These novel correlations between integrin mRNA expression and number of live foetuses, percentage prenatal survival and percentage of male foetuses in the litter which, considering the importance of these characteristics post-natally, may be of interest to investigate further.

Importantly, this study has demonstrated that endometrial SPP1 expression was associated with both foetal size and sex, suggesting the actions of SPP1 at the foeto-maternal interface are associated with foetal development. Binding of SPP1 to the ITGAVB3 receptor has been demonstrated to activate the Akt (Protein Kinase B)/eNOS (endothelial nitric oxide synthase) signalling pathway, leading to increased proliferation, migration and tube formation of endothelial cells in vitro (Dai et al. 2009, Wang et al. 2011). Dunlap et al. (2008) demonstrated in the sheep a relationship between uterine von Willebrand Factor (vWF) staining and SPP1, and that uterine arterial endothelial cells produce SPP1 during angiogenesis in vitro. Analysis of GD9, 12 and 15 porcine endometrial samples identified the presence of a $32 \mathrm{kDA}$ fragment of SPP1, which is known to bind to the cell surface of endothelial cells (Erikson et al. 2009b, Bayless et al. 2010). In these studies, in vitro experiments using blood samples from new-born piglets demonstrated that SPP1 has a positive effect on the migration and adhesion of endothelial cells, suggesting a potential role in regulating placental and endometrial angiogenesis. At the pig foeto-maternal interface, there are two keys stages of gestation when angiogenesis occurs. The first is at GD13-18 (Keys et al. 1986), which corresponds to the period of conceptus attachment, and the second wave of angiogenesis occurs at approximately GD50 (Vonnahme et al. 2001), which corresponds to the period when placental growth is beginning to plateau and the foetus is about to undergo exponential growth. An additional study utilising the same samples used in the present study revealed striking associations between foetal size and sex and angiogenesis at the foetomaternal interface, which were dependent on the GD investigated (Stenhouse 2018a,b). Therefore, considering the role of SPP1 and ITGAVB3 during implantation (Erikson et al. 2009a, Frank et al. 2017) and the results of the current study, it could be hypothesised that SPP1 has an additional role in inducing altered angiogenesis in foetuses of different size and sex which should be investigated further.

\section{Conclusion}

A comprehensive temporal analysis of the mRNA expression of key integrin subunits, $F N$ and SPP1 throughout gestation in both placental and endometrial samples was performed, identifying previously undescribed temporal changes in integrin expression. Endometrial expression of ITGB1 and SPP1 was decreased in samples associated with the lightest foetuses compared to samples supplying their normally grown littermates at GD45 and 60 respectively. Overall, this demonstrated that foetal size is related to integrin signalling at the foeto-maternal interface but surprisingly this appears to occur in a temporal manner. Novel associations between foetal sex and the expression of ITGB3, ITGB6, SPP1 and FN at the foeto-maternal interface were also observed. The results presented in this study are intriguing and the mechanisms behind these differences warrant further investigation, especially during preimplantation development and early pregnancy.

\section{Supplementary data}

This is linked to the online version of the paper at https://doi.org/10.1530/REP-18-0520.

\section{Declaration of interest}

The authors declare that there is no conflict of interest that could be perceived as prejudicing the impartiality of the research reported.

\section{Funding}

The Roslin Institute receives Institute Strategic Grant funding from the BBSRC (BB/J004316/1). C S was in receipt of a studentship from the University of Edinburgh.

\section{Acknowledgements}

The authors thank the staff of The Roslin Institute Large Animal Unit for skilled assistance, Chris Stenhouse for creating the conceptus floatation device and Dr Darren Shaw for statistical advice.

\section{References}

Aplin JD, Seif MW, Graham RA, Hey NA, Behzad F \& Campbell S 1994 The endometrial cell surface and implantation: expression of the polymorphic mucin MUC-1 and adhesion molecules during the endometrial cycle. Annals of the New York Academy of Sciences 734 103-121. (https://doi. org/10.1111/j.1749-6632.1994.tb21739.x)

Ashworth CJ, Finch AM, Page KR, Nwagwu MO \& McArdle HJ 2001 Causes and consequences of fetal growth retardation in pigs. Reproduction $\mathbf{5 8}$ 233-246.

Baxter EM, Jarvis S, Palarea-Albaladejo J \& Edwards SA 2012 The weaker sex? the propensity for male-biased piglet mortality. PLoS One 7 e30318. (https://doi.org/10.1371/journal.pone.0030318)

Bayless KJ, Erikson DW, Frank JW, Joyce MM, Burghardt RC, Bazer FW \& Johnson GA 2010 Recruitment and modulation of porcine endothelial progenitor cells by secreted phosphoprotein 1 (SPP1, osteopontin). Biology of Reproduction 83 94. (https://doi.org/10.1093/biolreprod/83. s1.94)

Bloor DJ, Metcalfe AD, Rutherford A, Brison DR \& Kimber SJ 2002 Expression of cell adhesion molecules during human preimplantation embryo development. Molecular Human Reproduction 8 237-245. (https://doi.org/10.1093/molehr/8.3.237)

Bowen JA, Bazer FW \& Burghardt RC 1996 Spatial and temporal analyses of integrin and Muc-1 expression in porcine uterine epithelium and 
trophectoderm in vivo. Biology of Reproduction 55 1098-1106. (https:// doi.org/10.1095/biolreprod55.5.1098)

Burghardt RC, Johnson GA, Jaeger LA, Ka H, Garlow JE, Spencer TE \& Bazer FW 2002 Integrins and extracellular matrix proteins at the maternal-fetal interface in domestic animals. Cells, Tissues, Organs 172 202-217. (https://doi.org/10.1159/000066969)

Burghardt RC, Burghardt JR, Taylor JD, Reeder AT, Nguen BT, Spencer TE, Bayless KJ \& Johnson GA 2009 Enhanced focal adhesion assembly reflects increased mechanosensation and mechanotransduction at maternal-conceptus interface and uterine wall during ovine pregnancy. Reproduction 137 567-582. (https://doi.org/10.1530/REP-08-0304)

Campbell S, Swann HR, Seif MW, Kimber SJ \& Aplin JD 1995 Cell adhesion molecules on the oocyte and preimplantation human embryo. Human Reproduction 10 1571-1578. (https://doi.org/10.1093/ HUMREP/10.6.1571)

Carson DD, Bagchi I, Dey SK, Enders AC, Fazleabas AT, Lessey BA \& Yoshinaga K 2000 Embryo implantation. Developmental Biology 223 217-237. (https://doi.org/10.1006/dbio.2000.9767)

Dai J, Peng L, Fan K, Wang H, Wei R, Ji G, Cai J, Lu B, Li B, Zhang D et al. 2009 Osteopontin induces angiogenesis through activation of PI3K/AKT and ERK1/2 in endothelial cells. Oncogene 28 3412-3422. (https://doi. org/10.1038/onc.2009.189)

Delon I \& Brown NH 2007 Integrins and the actin cytoskeleton. Current Opinion in Cell Biology 19 43-50. (https://doi.org/10.1016/j. ceb.2006.12.013)

Denker HW 1993 Implantation: a cell biological paradox. Journal of Experimental Zoology 266 541-558. (https://doi.org/10.1002/ jez.1402660606)

Drickamer LC, Arthur RD \& Rosenthal TL 1997 Conception failure in swine: importance of the sex ratio of a female's birth litter and tests of other factors. Journal of Animal Science 75 2192-2196. (https://doi. org/10.2527/1997.7582192x)

Drickamer LC, Rosenthal TL \& Arthur RD 1999 Factors affecting the number of teats in pigs. Journal of Reproduction and Fertility 115 97-100. (https://doi.org/10.1530/jrf.0.1150097)

Dunlap KA, Erikson DW, Burghardt RC, White FJ, Reed KM, Farmer JL, Spencer TE, Magness RR, Bazer FW, Bayless KJ et al. 2008 Progesterone and placentation increase secreted phosphoprotein one (SPP1 or osteopontin) in uterine glands and stroma for histotrophic and hematotrophic support of ovine pregnancy. Biology of Reproduction 79 983-990. (https://doi.org/10.1095/biolreprod.108.071068)

Erikson DW, Burghardt RC, Bayless KJ \& Johnson GA 2009a Secreted phosphoprotein 1 (SPP1, osteopontin) binds to integrin alphavbeta 6 on porcine trophectoderm cells and integrin alphavbeta3 on uterine luminal epithelial cells, and promotes trophectoderm cell adhesion and migration. Biology of Reproduction 81 814-825. (https://doi. org/10.1095/biolreprod.109.078600)

Erikson DW, Burghardt RC, Bazer FW, Johnson GA \& Bayless KJ 2009b Secreted phosphoprotein 1 (SPP1, osteopontin) stimulates adhesion and migration of circulating endothelial cells in pigs. Biology of Reproduction 81 91. (https://doi.org/10.1093/biolreprod/81.s1.91)

Erkens T, Van Poucke M, Vandesompele J, Goossens K, Van Zeveren A \& Peelman LJ 2006 Development of a new set of reference genes for normalization of real-time RT-PCR data of porcine backfat and longissimus dorsi muscle, and evaluation with PPARGC1A. Biomed Central Biotechnology 6 1-8.(https://doi.org/10.1186/1472-6750-6-41)

Fassler R \& Meyer M 1995 Consequences of lack of beta 1 integrin gene expression in mice. Genes and Development 9 1896-1908. (https://doi. org/10.1101/gad.9.15.1896)

Fazleabas AT, Bell SC, Fleming S, Sun J \& Lessey BA 1997 Distribution of integrins and the extracellular matrix proteins in the baboon endometrium during the menstrual cycle and early pregnancy. Biology of Reproduction 56 348-356. (https://doi.org/10.1095/biolreprod56.2.348)

Feinberg RF, Kliman HJ \& Lockwood CJ 1991 Is oncofetal fibronectin a trophoblast glue for human implantation? American Journal of Pathology 138 537-543.

Finch AM, Anitpatis C, Pickard AR \& Ashworth CJ 2002 Patterns of fetal growth within large white $X$ landrace and Chinese Meishan gilt litters at three stages of gestation. Reproduction, Fertility and Development $\mathbf{1 4}$ 419-425. (https://doi.org/10.1071/RD01131)

Ford SP, Vonnahme KA \& Wilson ME 2002 Uterine capacity in the pig reflects a combination of uterine environment and conceptus genotype effects. Journal of Animal Science 80 E66-E73. (https://doi.org/10.2527/ animalsci2002.0021881200800ES10010x)

Foxcroft GR \& Town SC 2004 Prenatal programming of postnatal performance - the unseen cause of variance. Advances in Pork Production 15 4-10.

Foxcroft GR, Dixon WT, Novak S, Putman CT, Town SC \& Vinsky MDA 2006 The biological basis for prenatal programming of postnatal performance in pigs. Journal of Animal Science 84 E105-E112. (https:// doi.org/10.2527/2006.8413_supplE105x)

Frank JW, Seo H, Burghardt RC, Bayless KJ \& Johnson GA 2017 ITGAV (alpha $\vee$ integrins) bind SPP1 (osteopontin) to support trophoblast cell adhesion. Reproduction 153 695-706. (https://doi.org/10.1530/REP-170043)

Gallant ND, Michael KE \& García AJ 2005 Cell adhesion Strenthening: contributions of adhesive area, integrin binding, and focal adhesion assembly. Molecular Biology of the Cell 16 4329-4340. (https://doi. org/10.1091/mbc.e05-02-0170)

Garlow JE, Ka H, Johnson GA, Burghardt RC, Jaeger LA \& Bazer FW 2002 Analysis of osteopontin at the maternal-placental interface in pigs. Biology of Reproduction 66 718-725. (https://doi.org/10.1095/ biolreprod66.3.718)

Germeyer A, Savaris RF, Jauckus J \& Lessey B 2014 Endometrial beta3 integrin profile reflects endometrial receptivity defects in women with unexplained recurrent pregnancy loss. Reproductive Biology and Endocrinology 12 53. (https://doi.org/10.1186/1477-7827-12-53)

Giancotti FG \& Ruoslahti E 1999 Integrin signaling. Science 285 1028-1032. (https://doi.org/10.1126/science.285.5430.1028)

Gonzalez TL, Sun T, Koeppel AF, Lee B, Wang ET, Farber CR, Rich SS, Sundheimer LW, Buttle RA, Chen YI et al. 2018 Sex differences in the late first trimester human placenta transcriptome. Biology of Sex Differences 9 4. (https://doi.org/10.1186/s13293-018-0165-y)

Górecki MT 2003 Sex ratio in litters of domestic pigs (Sus scrofa f. domestica Linnaeus, 1758). Biology Letters 40 111-118.

Guillomot M 1999 Changes in extracellular matrix components and cytokeratins in the endometrium during goat implantation. Placenta 20 339-345. (https://doi.org/10.1053/plac.1998.0385)

Hernández SC, Hogg CO, Billon Y, Sanchez MP, Bidanel JP, Haley CS, Archibald AL \& Ashworth CJ 2013 Secreted phosphoprotein 1 expression in endometrium and placental tissues of hyperprolific large white and Meishan gilts. Biology of Reproduction 88 120. (https://doi.org/10.1095/ biolreprod.112.104679)

Hodivala-Dilke KM, Mchugh KP, Tsakiris DA, Rayburn H, Crowley D, Ullman-Cullere M, Ross FP, Coller BS, Teitelbaum S \& Hynes RO 1999 $\beta 3$-integrin-deficient mice are a model for Glanzmann thromboasthenia showing placental defects and reduced survival. Journal of Clinical Investigation 103 229-238. (https://doi.org/10.1172/JCI5487)

Huhn R, Tuchscherer A, Breite L, Grodzycki M \& Huhn U 2002 Influence of base litter sex ratio of gilts on their subsequent reproductive performances. Zuchtungskunde 74 56-69.

Humphries JD, Byron A \& Humphries MJ 2006 Integrin ligands at a glance. Journal of Cell Science 119 3901-3903. (https://doi.org/10.1242/jcs.03098)

Illera MJ, Cullinan E, Gui Y, Yuan L, Beyler SA \& Lessey BA 2000 Blockade of the $\alpha v \beta 3$ integrin adversely affects implantation in the mouse. Biology of Reproduction 62 1285-1290. (https://doi.org/10.1095/ biolreprod62.5.1285)

Illera MJ, Lorenzo PL, Gui YT, Beyler SA, Apparao KBC \& Lessey BA 2003 A role for $\alpha v \beta 3$ integrin during implantation in the rabbit model. Biology of Reproduction 68 766-771. (https://doi.org/10.1093/ biolreprod/68.3.766)

Imakawa K, Imai M, Sakai A, Suzuki M, Nagaoka K, Sakai S, Lee SR, Chang KT, Echternkamp SE \& Christenson RK 2006 Regulation of conceptus adhesion by endometrial CXC chemokines during the implantation period in sheep. Molecular Reproduction and Development 73 850-858. (https://doi.org/10.1002/mrd.20496)

Irving JA \& Lala PK 1995 Functional role of cell surface integrins on human trophoblast cell migration: regulation by TGF- $\beta$, IGF-II, and IGFBP-1. Experimental Cell Research 217 419-427. (https://doi.org/10.1006/ excr.1995.1105)

Johnson GA, Burghardt RC, Spencer TE, Newton GR, Ott TL \& Bazer FW 1999 Ovine osteopontin: II. Osteopontin and $\alpha \mathrm{V} \beta 3$ integrin expression in the uterus and conceptus during the periimplantation period. Biology of Reproduction 61 892-899. (https://doi.org/10.1095/biolreprod61.4.892) 
Johnson GA, Bazer FW, Jaeger LA, Ka H, Garlow JE, Pfarrer C, Spencer TE \& Burghardt RC 2001 Muc-1, integrin, and osteopontin expression during the implantation cascade in sheep. Biology of Reproduction 65 820-828. (https://doi.org/10.1095/biolreprod65.3.820)

Kalisch-Smith JI, Simmons DG, Dickinson H \& Moritz KM 2017 Review: sexual dimorphism in the formation, function and adaptation of the placenta. Placenta 54 10-16. (https://doi.org/10.1016/j. placenta.2016.12.008)

Kao LC, Tulac S, Lobo S, Imani B, Yang JP, Germeyer A, Osteen K, Taylor RN, Lessey BA \& Giudice LC 2002 Global gene profiling in human endometrium during the window of implantation. Endocrinology 143 2119-2138. (https://doi.org/10.1210/endo.143.6.8885)

Keys JL, King GJ \& Kennedy TG 1986 Increased uterine permeability at the time of embryonic attachment in the pig. Biology of Reproduction 34 405-411. (https://doi.org/10.1095/biolreprod34.2.405)

Kimmins S \& MacLaren LA 1999 Cyclic modulation of integrin expression in bovine endometrium. Biology of Reproduction 61 1267-1274. (https://doi.org/10.1095/biolreprod61.5.1267)

King DP, Burman A, Gold S, Shaw AE, Jackson T \& Ferris NP 2011 Integrin sub-unit expression in cell cultures used for the diagnosis of foot-andmouth disease. Veterinary Immunology and Immunopathology $\mathbf{1 4 0}$ 259-265. (https://doi.org/10.1016/j.vetimm.2011.01.008)

Koketsu Y, Tani S \& lida R 2017 Factors for improving reproductive performance of sows and herd productivity in commercial breeding herds. Porcine Health Management 3 1. (https://doi.org/10.1186/ s40813-016-0049-7)

Lamberson WR, Blair RM, Rohde Parfet KA, Day BN \& Johnson RK 1988 Effect of sex ratio of the birth litter on subsequent reproductive performance of gilts. Journal of Animal Science 66 595-598. (https://doi. org/10.2527/jas1988.663595x)

Lessey BA, Castelbaum AJ, Buck CA, Lei Y, Yowell CW \& Sun J 1994 Further characterization of endometrial integrins during the menstrual cycle and in pregnancy. Fertility and Sterility 62 497-506. (https://doi. org/10.1016/S0015-0282(16)56937-4)

Lin H, Wang X, Liu G, Fu J \& Wang A 2007 Expression of $\alpha$ V and $\beta 3$ integrin subunits during implantation in pig. Molecular Reproduction and Development 74 1379-1385. (https://doi.org/10.1002/mrd.20732)

Marrable AW 1971 The Embryonic Pig: A Chronological Account. London: Pitman Medical.

Montiel JF, Kaune H \& Maliqueo M 2013 Maternal-fetal unit interactions and eutherian neocortical development and evolution. Frontiers in Neuroanatomy 7 22. (https://doi.org/10.3389/fnana.2013.00022)

Nygard AB, Jørgensen CB, Cirera S \& Fredholm M 2007 Selection of reference genes for gene expression studies in pig tissues using SYBR green qPCR. Biomed Central Molecular Biology 8 1-6. (https://doi. org/10.1186/1471-2199-8-67)

Pettigrew JE, Cornelius SG, Moser RL, Heeg TR, Hanke HE, Miller KP \& Hagen CD 1986 Effects of oral doses of corn oil and other factors on preweaning survival and growth of piglets. Journal of Animal Science $\mathbf{6 2}$ 601-612. (https://doi.org/10.2527/jas1986.623601x)

Qin L, Wang YL, Bai SX, Ji SH, Qiu W, Tang S \& Piao YS 2003 Temporal and spatial expression of integrins and their extracellular matrix ligands at the maternal-fetal interface in the rhesus monkey during pregnancy. Biology of Reproduction 69 563-571. (https://doi.org/10.1095/ biolreprod.103.015198)

Rashev P, Georgieva R \& Rees D 2005 Expression of $\alpha 5 \beta 1$ integrin and fibronectin during early pregnancy in pigs. Folia Biologica 51 121-125.

Rosenfeld CS 2015 Sex-specific placental responses in fetal development. Endocrinology 156 3422-3434. (https://doi.org/10.1210/en.2015-1227)

Ruck P, Marzusch K, Kaiserling E, Horny HP, Dietl J, Geiselhart A, Handgretinger R \& Redman CW 1994 Distribution of cell adhesion molecules in decidua of early human pregnancy. An immunohistochemical study. Laboratory Investigation 71 94-101.

Schultz JF \& Armant DR $1995 \beta 1$ - and $\beta 3$-class integrins mediate fibronectin binding activity at the surface of developing mouse peri-implantation blastocysts. Journal of Biological Chemistry 270 11522-11531. (https:// doi.org/10.1074/jbc.270.19.11522)

Schultz JF, Mayernik L, Rout UK \& Armant DR 1997 Integrin trafficking regulates adhesion to fibronectin during differentiation of mouse periimplantation blastocysts. Developmental Genetics 21 31-43. (https://doi. org/10.1002/(SICl)1520-6408(1997)21:1<31::AID-DVG4>3.0.CO;2-9)
Schwartz MA \& Assoian RK 2001 Integrins and cell proliferation: regulation of cyclin-dependent kinases via cytoplasmic signaling pathways. Journal of Cell Science 114 2553-2560.

Shiokawa S, Yoshimura Y, Nagamatsu S, Sawa H, Hanashi H, Koyama N, Katsumata Y, Nagai A \& Nakamura Y 1996 Function of $\beta 1$ integrins on human decidual cells during implantation. Biology of Reproduction $\mathbf{5 4}$ 745-752. (https://doi.org/10.1095/biolreprod54.4.745)

Shiokawa S, Yoshimura Y, Sawa H, Nagamatsu S, Hanashi H, Sakai K, Ando M \& Nakamura Y 1999 Functional role of Arg-Gly-Asp (RGD)-binding sites on $\beta 1$ integrin in embryo implantation using mouse blastocysts and human decidua. Biology of Reproduction $\mathbf{6 0}$ 1468-1474. (https://doi.org/10.1095/biolreprod60.6.1468)

Steinhauser CB, Bazer FW, Burghardt RC \& Johnson GA 2017 Expression of progesterone receptor in the porcine uterus and placenta throughout gestation: correlation with expression of uteroferrin and osteopontin. Domestic Animal Endocrinology 58 19-29. (https://doi.org/10.1016/j. domaniend.2016.07.002)

Stenhouse C 2018 Investigating the Porcine Feto-Maternal Interface Throughout Gestation: Associations with Foetuses of Different Size and Sex. PhD Thesis. University of Edinburgh.

Stenhouse C, Tennant P, Duncan WC \& Ashworth CJ 2018b Doppler ultrasound can be used to monitor umbilical arterial blood flow in lightly sedated pigs at multiple gestational ages. Reproduction, Fertility, and Development.30 1402-1411. (https://doi.org/10.1071/RD17298)

Stenhouse C, Hogg CO \& Ashworth CJ 2018a Associations between fetal size, sex and placental angiogenesis in the pig. Biology of Reproduction 100 239-252. (https://doi.org/10.1093/biolre/ioy184)

Stephens LE, Sutherland AE, Klimanskaya IV, Andrieux A, Meneses J, Pedersen RA \& Damsky CH 1995 Deletion of $\beta 1$ integrins in mice results in inner cell mass failure and peri-implantation lethality. Genes and Development 9 1883-1895. (https://doi.org/10.1101/gad.9.15.1883)

Sutherland AE, Calarco PG \& Damsky CH 1993 Developmental regulation of integrin expression at the time of implantation in the mouse embryo. Development 119 1175-1186.

Vallet JL \& Freking BA 2007 Differences in placental structure during gestation associated with large and small pig fetuses. Journal of Animal Science 85 3267-3275. (https://doi.org/10.2527/jas.2007-0368)

Vallet JL, McNeel AK, Miles JR \& Freking BA 2014 Placental accommodations for transport and metabolism during intra-uterine crowding in pigs. Journal of Animal Science and Biotechnology 51.

Vélez C, Williamson D, Riesco O, Martín P, García M, Yaful G \& Koncurat M 2015 Estrogens, progesterone and integrin-fibronectin interaction during porcine placentation. Placenta 36 500. (https://doi. org/10.1016/j.placenta.2015.01.484)

Vélez C, Barbeito C \& Koncurat M $2017 \alpha v \beta 3$ integrin and fibronectin expressions and their relation to estrogen and progesterone during placentation in swine. Biotechnic and Histochemistry 7 1-7.

Vonnahme KA, Wilson ME \& Ford SP 2001 Relationship between placental vascular endothelial growth factor expression and placental/endometrial vascularity in the pig. Biology of Reproduction 64 1821-1825. (https:// doi.org/10.1095/biolreprod64.6.1821)

Wang Y, Yan W, Lu X, Qian C, Zhang J, Li P, Shi L, Zhao P, Fu Z, Pu P et al. 2011 Overexpression of osteopontin induces angiogenesis of endothelial progenitor cells via the av $\beta 3 / \mathrm{PI} 3 \mathrm{~K} / \mathrm{AKT} / \mathrm{eNOS} / \mathrm{NO}$ signaling pathway in glioma cells. European Journal of Cell Biology 90 642-648. (https://doi.org/10.1016/j.ejcb.2011.03.005)

White FJ, Ross JW, Joyce MM, Geisert RD, Burghardt RC \& Johnson GA 2005 Steroid regulation of cell specific secreted phosphoprotein 1 (osteopontin) expression in the pregnant porcine uterus. Biology of Reproduction $\mathbf{7 3}$ 1294-1301. (https://doi.org/10.1095/biolreprod.105.045153)

White FJ, Burghardt RC, Hu J, Joyce MM, Spencer TE \& Johnson GA 2006 Secreted phosphoprotein 1 (osteopontin) is expressed by stromal macrophages in cyclic and pregnant endometrium of mice, but is induced by estrogen in luminal epithelium during conceptus attachment for implantation. Reproduction 132 919-929. (https://doi.org/10.1530/ REP-06-0068)

Widdowson EM 1971 Intra-uterine growth retardation in the pig I Organ Size and cellular development at birth and after growth to maturity. Biology of the Neonate 19 329-340. (https://doi.org/10.1159/000240427)

Wise T, Roberts AJ \& Christenson RK 1997 Relationships of light and heavy fetuses to uterine position, placental weight, gestational age, and fetal 
cholesterol concentrations. Journal of Animal Science 75 2197-2207. (https://doi.org/10.2527/1997.7582197x)

Wu G, Bazer FW, Burghardt RC, Johnson GA, Kim SW, Li XL, Satterfield MC \& Spencer TE 2010 Impacts of amino acid nutrition on pregnancy outcome in pigs: mechanisms and implications for swine production. Journal of Animal Science 88 E195-E204. (https://doi.org/10.2527/ jas.2009-2446)

Yelich JV, Pomp D \& Geisert RD 1997 Detection of transcripts for retinoic acid receptors, retinol-binding protein, and transforming growth factors during rapid trophoblastic elongation in the porcine conceptus. Biology of Reproduction 57 286-294. (https://doi.org/10.1095/biolreprod57.2.286)

Yoshimura Y, Shiokawa S, Nagamatsu S, Hanashi H, Sawa H, Koyama N, Katsumata Y \& Nakamura Y 1995 Effects of beta-1 integrins in the process of implantation. Hormone Research 44 36-41. (https://doi. org/10.1159/000184659)

Zheng J, Wen YX, Austin JL \& Chen DB 2006 Exogenous nitric oxide stimulates cell proliferation via activation of a mitogen-activated protein kinase pathway in ovine fetoplacental artery endothelial cells. Biology of Reproduction 74 375-382. (https://doi.org/10.1095/ biolreprod.105.043190)

Zygmunt M, Boving B, Wienhard J, Münstedt K, Braems G, Bohle RM \& Lang U 1997 Expression of cell adhesion molecules in the extravillous trophoblast is altered in IUGR. American Journal of Reproductive Immunology 38 295-301. (https://doi.org/10.1111/j.1600-0897.1997. tb00518.x)

Received 5 October 2018

First decision 19 November 2018

Revised manuscript received 4 December 2018

Accepted 16 January 2019 